\title{
MOLECULAR BIOLOGY AND GENETICS
}

Comparison Analysis of Genetic Diversity of Indonesian Mangosteens (Garcinia mangostana L.) 163-167 and Related Species by using on Isozymes and AFLP Markers

SOBIR, SOALOON SINAGA, ROEDHY POERWANTO, RISMITASARI, RUDY LUKMAN

TAXONOMY, BIOSYSTEMATICS, AND PHYLOGENETICS

Genetic Relationship of Sago Palm (Metroxylon sagu Rottb.) in Indonesia Based on RAPD

Markers

BARAHIMA ABBAS, MUHAMMAD HASIM BINTORO, SUDARSONO, MEMEN SURAHMAN, HIROSHI EHARA

\section{ECOLOGY AND BIOLOGICAL CONSERVATION}

The Association of Mycorrhizal with Terrestrial Orchid Root in Mt. Cycloops Nature Reserve,

Jayapura

VERENA AGUSTINI, SUPENI SUFAATI, SUHARNO

Growth Rate of Acropora formosa Fragments that Transplanted on Artificial Substrate Made from Coral Rubble

NUR FADLI

Forest Dynamics of Peat Swamp Forest in Sebangau, Central Kalimantan

EDI MIRMANTO

Diversity and Abundance of Beetle (Coleoptera) Functional Groups in a Range of Land Use Systems in Jambi, Sumatra

FRANCISCUS XAVERIUS SUSILO, INDRIYATI, SURYO HARDIWINOTO

Population and Microhabitat Characteristic of Homalomena bellula Schott in Mount Slamet, Central Java, Indonesia

YAYAN WAHYU CANDRA KUSUMA, INGGIT PUJI ASTUTI

\section{OTHERS}

The Eschericia coli Growth Inhibition Activity of Some Fermented Medicinal Plant Leaf Extract from the Karo Highland, North Sumatra

EVI TRIANA, NOVIK NURHIDAYAT

REVIEW

Review: Current Advances in Gloriosa superba $L$. 
ISSN: 1412-033X (printed edition)

ISSN: 2085-4722 (electronic)

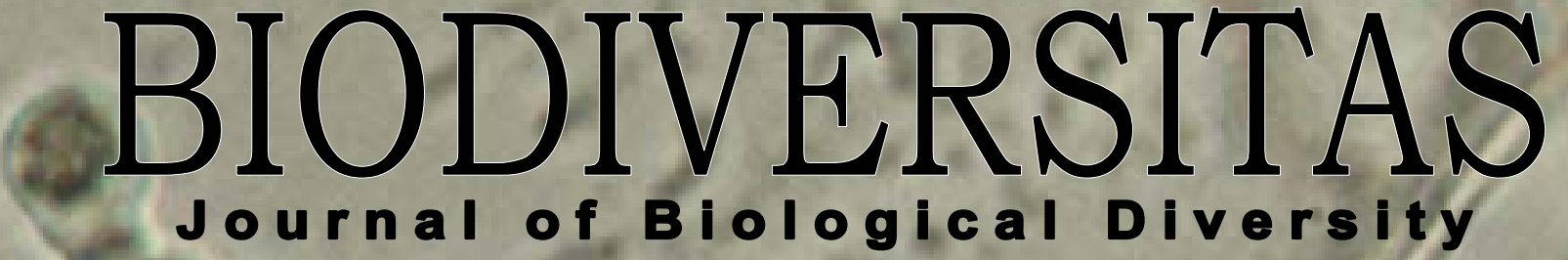

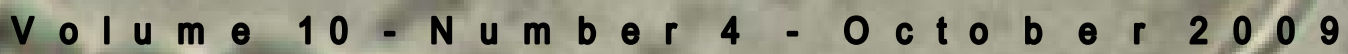

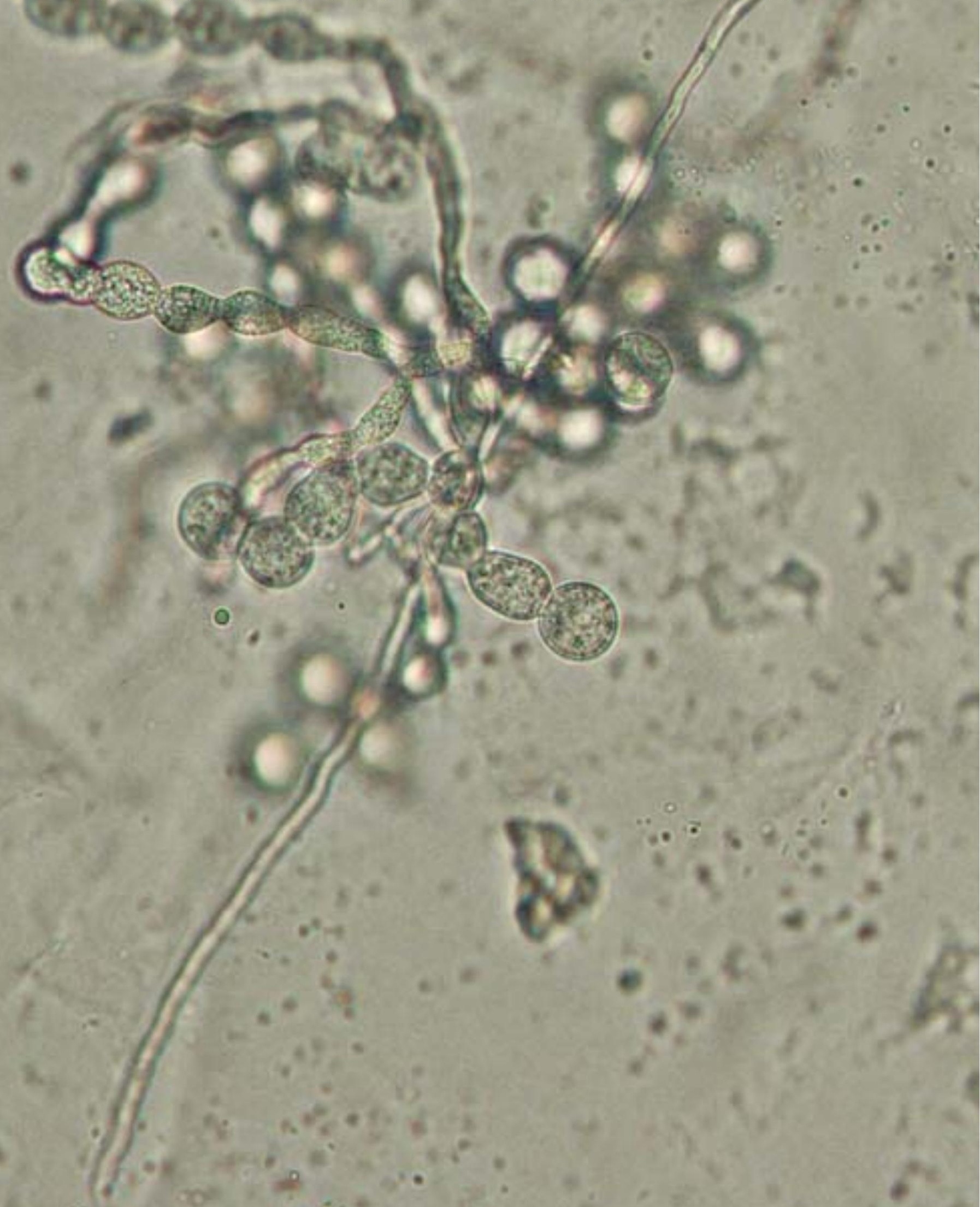

